\title{
Мобилизационные возможности Русской Православной Церкви по преодолению голода сельского населения 1891-1892 гг. в Российской империи
}

\begin{abstract}
Аннотаиия. В статье обобщаются результаты работы в рамках проекта РГНФ № 15-01-00026 «Кризис аграрного сочиума в имперской России: голод 1891-1892 г2. в Центрально-Черноземном регионе» за 2015 г. Автор уделяет внимание исследованию особенностей благотворительной деятельности Русской Православной Церкви в период голода 1891-1892 г. на примере Тульской губернии, относившейся к Земледельческому центру Российской империи. Основной акцент в статье делается на изучении активности иерковных институтов в механизме преодоления кризисных явлений в Российской империи в конце XIX в. Автор, на основе опубликованных источников и неопубликованных архивнъх материалов, анализирует деятельность Тульского епархиального комитета по помощи голодаюшим в период 1891-1892 гг. В статъе рассматриваются также особенности сочиальной и экономической ситуачии на уровне сельского прихода, анализируются отношения сельских обществ и клира в условиях чрезвычайной ситуачии. Проведенное исследование позволило сделать вывод, ито деятельность Русской Православной Церкви объективно способствовала преодолению кризиса аграрного сочиума в конце ХІХ в. Включение РПЦ в решение сочиальных и экономических проблем проходило в режиме форсированной мобилизачии, ито дало основание автору говорить об исключительных мобилизаиионных возможностях ведущей конфессии империи в условиях кризисных ситуаиий.
\end{abstract}

Ключевые слова: империя, Русская Православная Церковъ, духовенство, крестьянство, голод, благотворительность, епархиальный комитет, сочиальное служение, приход, крестьянская община.

Abstract. The article summarises the results of the work conducted within the framework of the project RGNF no. 15-0100026 "the Crisis of Agrarian Communities in Imperial Russian: the Famine of 1891-1892 in the Central-Chernozyomny Region" in 2015. The author focuses attention on the examination of the features of the Russian Orthodox Church's charitable activity during the period of the famine in 1891-1892 on the example of the Tula governorate, which belonged to the Agrarian centre of the Russian Empire. The article in particular highlights the investigation of the ecclesiastical institutes' activities in the push to overcome the crisis in the Russian Empire at the end of the 19th century. The author, on the basis of published sources and unpublished archival material, analyses the activity of the Tula eparchial committee in aiding the starving population during the period of 1891-1892. The article also examines the particularities of the social and economic situation at the level of the rural parish, analyses the relationship between agrarian societies and the clergy under the condition of an emergency situation. The conducted research has allowed to come to the conclusion that the efforts of the Russian Orthodox Church objectively contributed to overcoming the crisis of the agrarian community at the end of the 19th century. The inclusion of the Russian Orthodox Church in solving the social and economic problems happened in a mode of a forced mobilisation, which gives ground for the author to talk about the exceptional mobilisation possibilities of the Empire's leading religious confession under the conditions of a crisis.

Key words: empire, Russian Orthodox Church, clergy, peasantry, famine, charity, eparchial committee, social service, parish, peasant community.

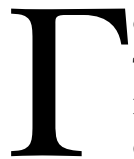
олод в России-это всегда масштабная трагедия, независимо от исторического периода. Но голод начала 1890-х гг. посвоему интересен и познавателен.
С одной стороны, неурожай и голод 18911892 гг. продемонстрировали уязвимость российской социально - экономической конструкции, включавшей в себя как структуры, сформи-

Исследование выполнено в рамках проекта РГНФ № 15-01-00026 «Кризис аграрного соичиума в имперской России: голод 1891-1892 гг. в Центрально-Черноземном регионе» 


\section{Исторический журнал: научные исследования № 1 (31) • 2016}

DOI: $10.7256 / 2222-1972.2016 .1 .17309$

ровавшиеся в ходе модернизационного рывка 1860-1870-х гг., так и многовековые институты, правовой статус которых был не понижен, а укреплен обширным законодательством эпохи Освобождения. Здесь мы, прежде всего, имеем в виду крестьянскую поземельную общину, получившую правовой статус «земельного общества», и взявшую под контроль ключевые вопросы землепользования и налогообложения. Неэффективность общинного управления в этих вопросах, в значительной степени, спровоцировала консервативный поворот в аграрной политике на исходе 1880-х гг.

А неурожай 1891 г., затронувший 29 из 97 губерний и областей России, обозначил и неадаптированность деревни земледельческого центра России или общинной деревни, к жестким условиям рынка[3, с. 147].

С другой стороны, в этот непродолжительный период были продемонстрированы и существенные мобилизационные возможности государственных, общественных и частных институтов, направленные на преодоление чрезвычайной ситуации в стране, что имело положительное значение. Особый комитет по оказанию помощи населению губерний, пострадавших от неурожая, образованный 18 ноября 1891 г. и возглавляемый наследником-цесаревичем Николаем Александровичем, располагал, по мнению О. Г. Вронского, исчерпывающей информацией о ситуации в деревне земледельческого центра страны [3, с. 147]. Информированность стала одним из ключевых факторов, позволивших Александру III провести активную кампанию по борьбе с неурожаем, в результате которой «правительственная помощь предотвратила реальную угрозу массового голода» [29, p. 173].

Не следует игнорировать и не менее эффективные мобилизационные возможности Русской Православной Церкви, одной из первых оказавшейся перед необходимостью скорейшего преодоления тяжелых последствий неурожая 1891 г., ощущаемых не только паствой, но и клиром. Мы полагаем, что в условиях чрезвычайной ситуации, в которой оказались многие епархии Земледельческого центра России, Церковь как институт тесно связанный не только с государством, но и с обществом располагала определенными организационными возможностями для того, чтобы выявить масштабы бедствия, в том числе поименно определить нуждающихся селян, организовать взаимодействие губернаторов, земств, отделений Красного креста, пред- принимательского класса, земских начальников, крестьянских обществ, адресно распределить материальную и денежную помощь. Эта серьезная работа в современной историографии не получила должной положительной оценки. Деятельность Церкви находится в тени государственных и земских инициатив, что не вполне справедливо, потому что ведущая конфессия проделала ощутимый объем работы в условиях чрезвычайной ситуации в форсированные сроки. Все это позволяет применять в настоящей статье с определенной долей условности термин «мобилизационные возможности», понимая под ним не деятельность государства в условиях войны[18], но способность Церкви в форсированном режиме собрать материальные ресурсы, а также наладить эффективное взаимодействие государственных, общественных, частных и церковных институтов.

Обращение к региональным неопубликованным и опубликованным источникам позволяет провести изучение благотворительной деятельности Русской Православной Церкви в период голода 1891-1892 гг. в пределах Тульской-Белевской епархии, отнесенной к числу территорий, наиболее охваченных неурожаем. Одновременно мы рассмотрим и особенности социальной ситуации, сложившейся под влиянием неурожая и голода на уровне сельского прихода, выявим специфику взаимоотношений клира и мирян в обозначенный период.

Объективность исследования мобилизационных возможностей Русской Церкви в направлении оказания помощи пострадавшим от неурожая требует уточнения территориальных границ продовольственного бедствия в пределах Тульской губернии. В докладе тульского губернатора за 1891 г. отмечалось, что от неурожая пострадало население основных земледельческих уездов - Богородицкого, Ефремовского, Епифанского, Чернского, Новосильского и частично крестьянство Веневского, Крапивенского, Каширского, Тульского уездов [16, с.1-2], т. е. примерно территории губернии. Неурожаем не были затронуты Алексинский, Белевский, Одоевский уезды. К тому же население этих уездов имело возможность «отходить» в Москву или Калужскую губернию, составляя основу фабрично-заводского контингента, и не особенно страдало от высоких цен на хлеб, а также другие сельскохозяйственные продукты. Хотя цены на сельхозпродукцию выросли значительно. Так, цена на рожь поднялась на 4 р. 21 коп. - с 4, 85 р. в 1890 г. до 9, 06 р. в 1891; 
Верования, религии, Церкви

DOI: $10.7256 / 2222-1972.2016 .1 .17309$

стоимость овса за четверть повысилась на 48 коп. (с 3, 22 в 1890 г. до 3,70 р. в 1891 г.) и гречихи - 2, 25 коп. (8,60 р. в 1890 г. и 10,85 р. в 1891 г.) [16, c. 4]. Подобный скачок на рынке по ржи, овсу и гречихе, составлявших основу крестьянского жизнеобеспечения, не мог не сказаться на снижении покупательной активности сельского населения в период август-декабрь 1891 г. и на резком падении уровня жизни этого сословия в обозначенных уездах Тульской губернии. Исходя из особенностей распространения неурожая и голода в Тульской губернии, мы предполагаем, что в голодные годы наиболее активным должна была стать деятельность духовенства самых бедных уездов Богородицкого, Ефремовского, Епифанского, Новосильского и Чернского уездов. В тоже время в условиях «синодальной системы» какая-либо «низовая» активность, неузаконенная распоряжениями от ведомства православного исповедания, для сельских причтов была затруднительна.

Поэтому началом деятельности Русской Церкви по преодолению последствий неурожая следует считать опубликование Определения Святейшего Правительствующего Синода № 2139 от 21 августа 1891 г., которым был признан факт неурожая и грядущего голода в ряде губерний [19, с. 330-332 ]. Несколько позже - 1 сентября 1891 г. - был издан циркуляр министра внутренних дел И. Н. Дурново, в котором давалась положительная характеристика усилиям синодальных властей по борьбе с голодом, поразившим многие губернии Империи [20, с. 355-356].

Определение Синода положило начало процессу создания епархиальных комитетов по оказанию помощи населению губерний, пострадавших от неурожая. Документ обязывал архиереев учреждать «в епархиальных городах из духовных и светских лиц под своим, или же викарного епископа, председательством, особые комитеты для сбора от доброхотных дателей пожертвовании и распределения в епархиях, пострадавших от неурожая, пособий между лицами, коих крайняя бедность будет по удостоверена приходскими причтами, предоставив при сем преосвященным учреждать таковые комитеты и в уездных городах, с тем, чтоб комитет сии все собранные суммы немедленно отсылали в губернские комитеты. На попечение губернских комитетов надлежит особо возложить устройство бесплатных столовых при архиерейских домах, монастырях, церквах или иных учреждениях и открытие особых приютов для призрения детей, лишенных крова и пропитания» $[19$,
С. 331]. Подобная мера оказалась актуальна, в основном, для пострадавших губерний.

Однако комитеты создавались во всех епархиях как пострадавших от стихийного бедствия, так и вполне благополучных в экономическом отношении. К неблагополучным частям Империи были отнесены и основные губернии земледельческого центра России- Воронежская, Орловская, Рязанская, Тамбовская, Тульская.

Деятельность епархиальных комитетов по помощи голодающим нуждается в отдельном подробном исследовании, потому что за относительно непродолжительный период - сентябрь 1891 - июнь 1892 гг. - они сумели наладить систему достаточно эффективной помощи голодающему сельскому населению, в том числе и бедствующим лицам из духовного сословия.

Деятельность аналогичной структуры в Тульской губернии, получившей официальное название «Тульский епархиальный комитет помощи голодающим духовного ведомства» (в документах он называется также Тульским епархиальным комитетом для сбора пожертвований в пользу голодающих от неурожая в Тульской губернии, и нередко просто Тульским епархиальным комитетом помощи голодающим), имела определенные хронологические рамки.

Тульский епархиальный комитет был учрежден 18 сентября 1891 г. Примерно в это же время с разницей в несколько дней создавались комитеты и в других епархиях[15, с. 364-365]. В состав его вошли представители от духовенства, власти, местной буржуазии, земства. В частности, от духовенства приняли участие в работе Комитета ректор семинарии, протоиерей А. И. Романов; кафедральный протоиерей А. Н. Иванов; ключарь, протоиерей П. П. Никольский; протоиерей М. А. Рождественский, протоиерей В. А. Рождественский, протоирей А. И. Никольский, протоиерей В. Н. Боголюбов, протоиерей П. М. Успенский, иеромонах Сергий (эконом архиерейского дома), священник А. Т. Владимирский. К числу светских лиц были отнесены губернатор Н.А. Зиновьев, кн. А. Д. Мышецкий, губернский предводитель дворянства А. А. Арсеньев, Г. Гилленшмидт, С. П. Денисьев, М. Т. Яблочков, И. К. Платонов, А. С. Баташев, И. С. Белобородов, Д. Я. Ваныкин, В. А. Постников, И. Ф. Белобородов, А. А. Любомудров, Н. С. Дружинин, Н. О. Мусатов, М. И. Петров [20, с. 375]. Таким образом, в состав нового чрезвычайного органа вошли те лица из провинциального сообщества, которые имели не только 


\section{Исторический журнал: научные исследования № 1 (31) • 2016}

DOI: $10.7256 / 2222-1972.2016 .1 .17309$

духовное влияние, но и определенные организационные, финансовые возможности для организации своевременной помощи нуждающемуся населению, и к тому же хорошо понимавшие не только экономические, но и социальные последствия неурожая и голода.

Первым решением епархиального комитета в губерниях, пострадавших от неурожая, должно было стать создание вертикальной структуры, в которую могли войти уездные комитеты и приходские (сельские) комитеты для оказания помощи голодающим. Подобная конструкция позволяла, как собирать достоверную информацию-осуществлять мониторинг әкономической ситуации на уровне прихода, так и наиболее адресно распределять поступающую помощь среди населения. Поэтому не случайно на своем первом заседании, состоявшемся 18 сентября 1891 г., Тульский епархиальный комитет постановил: «учредить немедленно сельские приходские Комитеты в местностях епархии, постигнутых неурожаем. В состав этих комитетов должны войти: местные в каждом селе священники, церковные старосты, лица, избранные из числа членов церковно-приходского попечительства самим же попечительством, а где нет попечительства-доверенные от прихожан. Признается полезным пригласить в сельского Комитета попечителя, назначаемого от земства для каждой волости или для нескольких волостей. Земского начальника, если не возможно будет иметь его постоянным членом сельского Комитета, по крайней мере, должно просить о возможном с его стороны содействии успешному ходу дел Комитета. Как составление Комитета, так и председательствование в них возложить на местных священников и на старшего, где более одного священника» [20, с. 374].

Однако более четкое предписание об образовании приходских комитетов было осуществлено Епархиальным комитетом только 17 октября 1891 г. На заседании Комитета месяц спустя, 18 ноября, было отмечено, что «наилучшим способом распределения помощи было признано устройство уездных комитетов в городах и приходских по селам» [21, с. 157]. Поэтому появление приходских комитетов в Тульской губернии осуществлялось со второй половины октября по декабрь 1891 г. Положение обязывало сельских священников, главным образом настоятелей храмов, брать на себя инициативу в деле формирования такого чрезвычайного органа. Вместе с отчетами о создании комитетов, духовенство направляло в Епархиальный комитет списки нуждающихся прихожан, что было отнесено к его непосредственным обязанностям.

Одними из первых стали ]организоваться комитеты в Ефремовском уезде: при Казанской церкви села Долматово Казинки тож - 25 октября 1891 года, при Георгиевской церкви в селе Кадном - 30 октября 1891 г. В списке, составленном священником прихода Казанской церкви, уже значилось 100 человек из числа жителей четырех поселений - села Долматово Казинки тоже, деревни Маховой, сельца Паново, деревни Писаревки [4, лл. 13-14]. По списку же прихода Георгиевской церкви от 30 октября 1891 г., объединявшем в начале 1890-х гг. одиннадцать селений численностью в 4033 человека, помощь требовалась 70 крестьянским семьям (396 человек) [4, лл. 219-220].

Наиболее остро стояло образование комитетов в тех приходах, где население уже находилось на грани физического выживания. Так, в списке нуждающихся в помощи крестьян села Никольское-Пономарево Ефремовского уезда от 28 октября 1891 г., составленном священниками Алексеем Прудовским и Василием Баженовым, указано 127 человек, самых беднейших из прихожан села Никольского-Пономарева, «которые и в урожайные годы с большим трудом прокармливаются, ныне же совершенно бедствуют» [4, л. 162].

Катастрофическая ситуация на селе определяла как состав, так и отчетность приходских комитетов: членство оказывалось довольно широким и представительным (входили не только духовенство и крестьяне-собственники, но и представители от земства, купечества, местного дворянства), а отчеты со списками голодающих, отправляемые в Епархию, получались максимально информативные. Интерес вызывает сам процесс формирования низшего элемента в системе церковной благотворительности в период неурожая и голода-приходского комитета.

Так, 14 ноября 1891 г. в приходе села Никитского Богородицкого уезда образовался комитет «О помощи нуждающимся в пропитании», в состав которого, помимо местных священников (П.П.Модестова,А.Г.Нащокина,Д. Т.Рождественского), вошли также церковный староста, волостной старшина, восемь сельских старост, по два доверенных от крестьян селений прихода и почетных членов-пристав 2 стана Богородицкого уезда Н. С. Бахтин, богородицкие купцы П. Г. Большаков, П. У. Банников и богородицкий мещанин Е. У. Банников. Всего - тридцать пять человек. Председателем комитета стал настоятель Троицкой церкви священник Петр Модестов [4, лл. 


\section{Верования, религии, Церкви}

DOI: $10.7256 / 2222-1972.2016 .1 .17309$

49-49об]. В планы комитета входило включение в его состав влиятельных фигур уезда: исправника г. Богородицка, земского начальника, управляющего имением графов Бобринских в селе Михайловском.

На первом заседании было постановлено «определить степень бедности приходских семейств, заслуживающих особого попечения со стороны комитета». Учитывая трехпоселенческий состав прихода, включавший село Никитское, образованное из шести слобод, и две деревни-Красный холм и Осиновый куст, составление списка голодающих являлось трудоемким делом даже для большого причта, состоящего из трех священников, дьякона и трех псаломщиков. В первой половине 1890-х гг. население прихода насчитывало 3680 лиц мужского и 3672 женского пола [28, с. 122]. В подробный список по разделам «с половины священника Модестова», «с половины священника Нащокина», «с половины священника Рождественского» вошло 69 семейств, из них 29 мужчин, 69 женщин, 68 детей. Всего-196 человек, далеко не большая часть прихода [4, лл. 50-53]. Внимание комитетчиков, естественно, оказалось обращено на наиболее нуждающихся жителей, не имеющих возможности пропитаться самостоятельно, каковыми могли оказаться малоземельные или безземельные крестьяне.

Эта категория, характерная для сельского социума земледельческого центра конца XIX в., оказалась на уровне исследуемого прихода довольно многослойной. В списке по приходу села Никитского преобладают вдовы бездетные и с детьми (безземельные или малоземельные), вдовы солдат, ограниченно дееспособные крестьяне (примечания священников - «слаба», «болезненна», «немощна», «сира и убога», «неизлечимо больна», «бездомные», «не кормит семью», «без топлива и без хлеба»), «бездомные и безземельные», в том числе сироты (например, сироты Арсениевы-Марфа 19 лет, Мария 12 лет, Михаил 9 лет, Павел 6 лет или «бездомный и безземельный» Владимир Тихонов Подшибякин, 13 лет). В отношении немногих прихожан замечалось: «лишен душевого надела» (как неизлечимо больной вдовец Иван Харитонов Давыдов, 72 лет, и его дочь девица Евфимия, 34 лет). В списке также имеются пометы священников, что крестьяне «земельные, но по неспособности хозяина крайне бедствуют». Таким образом, список бедствующих прихожан, отправляемый в Епархиальный комитет, являлся отражением сложной социальной структуры, сложившейся в пореформенную эпоху на уровне сельского прихода.
Заслуживает внимания и другая особенность развития чрезвычайной ситуации в Тульской губернии. Уже на стадии образования приходских комитетов масштабы продовольственного кризиса в уездах Тульской губернии, признанных пострадавшими от неурожая, существенно отличались. Об этом говорят отчеты причтов в Тульский епархиальный комитет и составленные ими же списки нуждающихся прихожан. Этот источник позволяет определить нам реальные масштабы продовольственного бедствия.

Наиболее тяжелая обстановка наблюдалась в Ефремовском уезде. В частности, в списке голодающих по приходу села Никольского на Птани Ефремовского уезда, составленным благочинным протоиереем Николаем Гастевым, значилось в качестве крайне нуждающихся в пропитании 979 человек («по части священника Протасова» указывались бедствующими крестьяне-собственники села Никольского-560 человек, а «по части протоиерея Гастева» к голодающим относилось 419 прихожан) [6, лл. 15-18об ]. При этом приход села Никольского на Птани, состоявший из восемнадцати поселений, насчитывал 3777 человек [28, с. 354].

В том же Ефремовском уезде клирики села Никольское-Пономарево 28 октября 1891 г., отмечали в дополнении к списку голодающих, что «бедствуют все прихожане за несколькими исключениями (десять домов на сто могут есть порядочный хлеб)... еще в августе приходилось видеть печеный хлеб, совершенно черный, который, при пробе, не стала есть собака; между тем этот хлеб составляет единственную пищу взрослых и детей $[. .$.$] За пожертвованиями на голода-$ ющих обратиться не к кому, все нуждаются, сами и просят помощи» [4, лл. 162-162об]. А приход села Никольское-Пономарево считался крупным, потому что он состоял из семи населенных пунктов общей численностью населения в 4245 крестьян-собственников и казенных крестьян [28, с. 386]. В приходе Архангельской церкви села Ступино священником Уаром Богоявленским было всего 108 беднейших крестьянина, нуждающихся в помощи Епархиального комитета, при том, что приход состоял из пяти поселений численностью в 2508 человек [4, лл.32-34]. Мы видим, что и в пределах Ефремовского уезда в октябре-декабре 1891 г. крайняя нужда сочеталась с еще относительным благополучием. Однако весной 1892 г. ситуация с хлебом во всех приходах станет более сложной: местные запасы продовольствия иссякнут, денежные ресурсы 


\section{Исторический журнал: научные исследования № 1 (31) • 2016}

DOI: $10.7256 / 2222-1972.2016 .1 .17309$

также заметно истощатся за долгую и голодную зиму. В этот период голод станет реальностью и для некогда крепких семей крестьян-собственников.

Непростой можно считать ситуацию и в приходах других уездов Тульской губернии. Так, в список голодающих прихожан Николаевской церкви села Никольского, что на Озерках Языково тож Чернского уезда от 5 декабря 1891 г. было внесено 506 крестьян [4, лл. 85850б]. Сам приход включал в себя десять поселений с общей численностью 3178 жителей [28, c. 716]. Священник Николаевской церкви Дмитрий Постников, характеризуя свою бедствующую паству, отмечал, что «все эти крестьяне в годы хорошего урожая всегда нищенствовали и были в поборе, а в нынешнем году в побор идти некуда» [4, с. 89 об ].

Но по остальным приходам Чернского уезда списки голодающих включают лишь самых бедных прихожан. Например, по приходу села Воскресенского на Роске указано только двенадцать нуждающихся крестьян; по приходу села Скородино указано сорок человек имеющих крайнюю нужду, из них большинство -это так называемые «николаевские солдаты» («николаевскими солдатами» называли евреев-рекрутов, начинавших службу с 12 лет. Призыв несовершеннолетних евреев на военную службу был установлен указом Николая I от 26 августа 1827 г. Имели право селиться за пределами «черты оседлости» - прим. Автора), не получавшие трех рублевого пособия в месяц, а также дворовые люди и мещане [4, лл. 97, 99-99об]. По приходу села Пашутино к нуждающимся были отнесены десять человек, не имевшие надела [6, 10об].

Близкая ситуация наблюдалась и в Новосильском уезде. Например, в списке прихода Димитриевской церкви Новосильского уезда указано только двадцать два крестьянина[4, лл. 121-121об]. В Епифанском уезде с осени продовольственную ситуацию взял под свой контроль Красный Крест, поэтому в списки сельских комитетов включали только тех немногих, до которых помощь этой организации просто не дошла [17, с.397]. Случалось, что в некоторых приходах в пострадавших уездах население равнодушно относилось к самой идее создания комитета и составлению списков голодающих. Так, в селе Солодилово Богородицкого уезда селяне не проявили интереса к этому делу, поэтому приходской комитет был сформирован из членов причта, церковного старосты и двух представи- телей от прихожан, который и выявил нуждающихся в количестве 20 человек [4, л. 82].

В уездах, для которых проблема неурожая и голода почти не существовала, тоже создавались сельские комитеты, но процесс организации и деятельности подобных структур в этом случае носил больше формальный характер и интересен исключительно для характеристики церковной дисциплины в поздний «синодальный период». Здесь показательно решение, которое принял 8 декабря 1891 г., комитет для вспомоществования голодающим при Сретенской церкви села Богучарово Тульского уезда (поместье известного дворянского рода Хомяковых), созданный 21 ноября 1891 г.: «так как, по приказанию Уездного предводителя волостным старшинам за подписом приходских священников и приложением Церковной печати, в семью от каждого прихода представить лиц, нуждающихся в насущном пропитании в общество красного Креста и волостной старшина Севрюковской волости представил из трех приходских деревень по одному двору действительно немогущих пропитаться урожаем текущего года-один по многосемейству, другой по слепоте, а третий по болезненному состоянию, то просить Епархиальный комитет выдавать пособие крестьянке деревни Севрюковки Елене Георгиевой Салтыковой с малолетним сыном, не имеющей ни дома, ни земельного надела» [4, л. 59].

Но и приходские комитеты в относительно благополучных уездах все же информировали церковное начальство о возможных скорых проблемах наиболее уязвимых членов социума-вдов и сирот-в связи с подорожанием хлеба. Так, комитет Крестовоздвиженской церкви села Яковлевского Тульского уезда от 26 ноября 1891 г. указывал в рапорте: «В нынешнем году нашу местность, по милости Божией, не постиг неурожай хлеба, а потому лиц, нуждающихся в насущном пропитании, не имеется, при сем нужно сказать, что к концу зимы и началу весны, вследствие дороговизны хлеба, будет много бедствующих семейств, особенно из вдов и сирот» $[8$, л.5].

Формирование приходских комитетов и определение количества голодающих крестьян по Тульской губернии завершилось в целом к концу декабря 1891 г. Одновременно Тульским епархиальным комитетом во взаимодействии с уездными и приходскими комитетами осуществлялась координация усилий государственных, частных, церковных структур по сбору и распределению пожертвований. 


\section{Верования, религии, Церкви}

DOI: $10.7256 / 2222-1972.2016 .1 .17309$

К 1 января 1892 г. сумма пожертвований и разных сборов в Тульский Епархиальный комитет составила 46072 р. 96 к. [23, с.21]. При этом нельзя недооценивать помощь из других епархиальных комитетов, которая была значительной. Так, в ноябре 1891 г. из общей собранной суммы в 5345 р., 2636 рубля было пожертвовано другими епархиями. Киевский епархиальный комитет пожертвовал два вагона ржи (1220 пуда) [21, с. 466]. К 20 декабря из собранных 10701 р. 68 коп. пожертвования от иных епархиальных комитетов составили 7277 р. 94 коп.[22, с.508]. В 1892 г. объем помощи заметно снизится. Важно, что проблема голода в Тульской епархии воспринималась населением иных епархий, в том числе и значительно удаленных от Земледельческого центра Российской империи, как общенациональная трагедия.

К 1 марта сумма, собранная Тульским епархиальным комитетом составляла 54671 р. 91 к. Но пожертвования сократились: в марте поступило в распоряжение Комитета только 979 р. 85 к. $[24$, с. 188$]$.

Одновременно со сбором средств, шло и их распределение. Так, с ноября 1891 по март 1892 г. Комитет израсходовал на нужды голодающих 8032 руб. и 16166 пудов [4, л. 120]. В марте 1892 г. Тульский епархиальный комитет, принимая во внимание усиление голода в большинстве уездов, «признал необходимым увеличить выдачу пособий как денежных, так и вещественных». Если в феврале 1892 г. голодающим двадцати одного села было выдано 1480 пудов хлеба, то в марте потрачено для раздачи голодающим через приходские комитеты тридцати двух сел уже денежного пособия 100 рублей и вещевого - 7200 пудов хлеба на продовольствие 5853 душ; устроено две пекарни на 594 и пять столовых на 490 человек. На содержание пекарен и столовой в марте отпущено 2350 пудов хлеба. Кроме того оказана помощь бедствующим лицам духовного звания- 750 рублей [9, лл.1-2]. Можно предположить, что период март-май 1892 г. стали временем наибольшей активности этого чрезвычайного органа.

Как проходило распределение помощи? На одном из первых заседаний Епархиального комитета в Туле 18 ноября 1891 г. было решено, после изучения списков голодающих от сельских комитетов разных уездов (в них также указывался священником размер желательной помощи конкретным семьям и лицам), выдавать сельским комитетам пособие для распределения го- лодающим в количестве, по приблизительному расчету, по 30 фунтов ржи или муки в месяц или по $1 \frac{1}{2}$ фунта печеного хлеба в день на каждого человека [21, с. 459].

Хлеб зерном или мукой направлялся в уезды. Денежная помощь практиковалась редко. За распределение помощи отвечал сельский комитет во главе с приходским священником. Священник Сергий Гумилевский в отчете о деятельности комитета своего прихода села Казанское-Греково Ефремовского уезда отмечал, что с декабря 1891 г. по март 1892 г. выдано на 741 душ хлебом 623 п. 30 ф., мукой-293 п. 20 ф. [13, л.2]. Действиями комитета в этом приходе, объединявшем шесть поселений, помощь была оказана хлебом и мукой 168 семьям, насчитывающим 671 человек. При этом ситуация продолжала оставаться, по мнению клирика, тяжелой: «...в деревнях Травино и Борисовские выселки с количеством 300 душ еще с зимы свирепствовал повальный тиф, многие и сейчас болят, народ крайне истощен и почти не может работать. Необходимо оказывать пособие, средств же в нашем комитете не имеется никаких, а посему деятельность оного совсем приостановилась. Пособия народонаселению нашего прихода до нового урожая требуется не менее 800 пудов муки или ржи»[13, лл.1-1об].

На проблему недостаточного снабжения голодающего крестьянства, как со стороны Тульского епархиального комитета, так и со стороны земства и Красного Креста обращали внимание и другие приходские священники. Так, иерей Георгий Моисеев из села Архангельского-Грязное Ефремовского уезда в рапорте от 12 января 1892 г. отмечал, что земская помощь по 30 фунтов муки на едока (безземельных и бывших дворовых крестьян) начинает доходить до беднейших семей, но крестьянин старается из этого пособия прокормить еще и скот, преимущественно лошадей, «к остальной муке прибавляет лебеду». Детям нужен нормальный хлеб «в таковых семьях бывают и больные, которым потребуется кусок ржаного чистого хлеба. Было несколько случаев: возвратившись от напутствования больного, с тем же ...посылал хлеба больному по его просьбе» [4, л.45].

Священник Николая Мерцалов из Ефремовского уезда также выражал обеспокоенность в рапорте от 10 марта 1892 г. отмечая, что «остается надежда на Тульский епархиальный комитет для вспомоществования голодающим в Тульской епархии, от которого голодающие и в моем приходе ожидать себе помощь. Нельзя же равно- 


\section{Исторический журнал: научные исследования № 1 (31) • 2016}

DOI: 10.7256/2222-1972.2016.1.17309

душно обходить то явление в народе, что получаемое им пособие в количестве 30 фунтов муки ржаной, иногда с примесью отрубей и простой муки, недостаточно, чтобы пропитаться целый месяц...до 300 человек самых бедных, не имеющих что либо продать или заложить» $[4$, л.208].

Действительно, во многих приходах, стремясь обеспечить наибольшее количество голодающих хлебом, члены комитетов значительно уменьшали норму, установленную Епархиальным комитетом в 30 фунтов на человека, чаще всего до $1 / 2$ пуда-20 фунтов. Но сельский комитет Введенской церкви села Верхоупье Богородицкого уезда под председательством священника Николая Струкова выдавал с 1 марта по 6 мая 1892 г. по $1 / 2$ фунта ржано-кукурузного печеного хлеба каждому нуждающемуся и таким образом распределил в течение тридцати пяти дней выпеченного хлеба 145 лицам всего 190 пуд 12 фунтов [10, л. 2об].

В некоторых приходах ситуацию спасала помощь от местного дворянства и купечества, являвшаяся дополнительным источником существования для бедствующих крестьян. Прихожанам села Сергиевского на Птани регулярно оказывалась помощь князем Д. М. Голицыным, членом комитета, часть имения которого (100 домов) составляла $1 / 3$ прихода. В частности, он разрешил собирать лист и хворост в своих лесах, обеспечил прокорм 150 крестьянских лошадей. Священник Сергий Макеев отмечал, что с марта 1892 г. «он начал выдавать муку тем из бывших своих крестьян, которые неспособны почему либо к физическому труду, а также вдовам и сиротам, каковых оказалось более пятидесяти человек» [7, л.10об]. Немалую помощь оказала причту и прихожанам села Ивановского на Ситовой Мечи Чернского уезда дочь московского купца Е. И. Гвоздакович, урожденная Прохорова, специально приехавшая в голодающий приход из заграницы. По ее инициативе были открыты четыре столовых на сто сорок человек, школа грамоты для девочек с бесплатным питанием; стала выдаваться еда для новорожденных крестьянских детей [26, с.300302]. Распространение получает и помощь от дворян, являвшихся земскими начальниками. Однако общей тенденцией была работа местных помещиков в составе приходских комитетов. Таких как артиллерии поручик Николай Алексеевич Елагин и отставной гвардии поручик Дмитрий Дмитриевич Левшин в составе приходского комитета села Новозаголичного Ефремовского уезда $[12$, л.1] или граф Владимир Бобринский, вхо- дивший в состав комитетов сел Верхоупья [10, л.2об] и Иовлева Богородицкого уезда [5, л.19].

Несомненно, деятельность в период голода 1891-1892 гг. в составе приходских комитетов представителей разных сословий и социальных групп способствовала не только консолидации усилий провинциального общества в решении частных задач на уровне прихода, но и преодолению продовольственного кризиса в масштабах губернии. Эта активность осуществлялась в рамках «вертикали» временных чрезвычайных органов, каковыми являлись комитеты по помощи голодающим-губернские, уездные, приходские. Неизбежное упразднение этой системы означало дезориентацию всей церковной благотворительности, целевой группой которой являлось голодающее крестьянство, являющееся основным элементом аграрного социума.

Миссия епархиальных комитетов по помощи голодающим завершается после 1 июня 1892 г., когда было издано предписание Св. Синода о прекращении по духовному ведомству с 1 июня 1892 г. сборов в пользу пострадавших от неурожая [27, с. 339-340]. Средства комитетов в епархиях, постигнутых неурожаем, передавались в местные губернские благотворительные комитеты. Предполагаем, что и Тульский комитет в июне прекращает свою деятельность.

Однако формальное завершение деятельности Тульского епархиального комитета по оказанию помощи голодающим не означало фактического окончания его трудов. В распоряжении Комитета к 1 мая находилось только 120 п. 27 ф. зерна и муки [25, с. 274]. Этих средств могло хватить на обеспечение только малочисленного прихода. Материальные возможности Комитета в Туле становились все более ограниченными. Но некоторые документы подтверждают, что Епархиальный комитет продолжал выполнение своей важной миссии до августа 1892 г. Так, 26 мая 1892 сельский комитет села Новозаголичного Ефремовского уезда распределил на 825 прихожан по пуда муки, всего 412 пудов [12, л. 5об]. Священник Георгиевской церкви села Закопы Ефремовского уезда Михаил Рождественский, отчитался 29 июля 1892 г.: о расходовании продуктов (250 пудов ржи) в мае и начале июня, полученных из Тульского епархиального комитета для помощи голодающим: «... потом из того же Комитета чрез местного Благочинного получено денег 270 рублей, на каковые деньги куплено муки в разное время 225 пудов по 1 руб. 20 коп. за пуд и мука роздана была во второй половине июня 140 п. и в первой половине июля 
Верования, религии, Церкви

DOI: $10.7256 / 2222-1972.2016 .1 .17309$

оставшиеся 85 пудов, каковую муку получала большая часть прихожан, так как пред наступлением уборки хлеба было ужасно много нуждающихся в кормлении...» $[14$, л.1]. Распределение помощи и составление отчетности по этому факту проходило до середины августа 1892 г. Некоторые направления благотворительной деятельности, инициированные Тульским епархиальным комитетом, прежде всего, бесплатные столовые для голодающих, открытые в некоторых селах, продолжали действовать и в июле 1892 г., как например, приходская столовая в селе Нижнее Скворчее Новосильского уезда [11].

И все же неурожай лета 1892 г. заставлял благочинных и приходское духовенство задумываться о предстоящей осени и зиме 1892-1893 гг. Благочинный 1 Епифанского округа священник Сергий Дружинин докладывал епархиальному начальству 20 июня 1892 г., что в приходе урожай «удовлетворительный, неудовлетворительный и скудный»: «При таких обстоятельствах, как и конец текущего года, так и будущий 1893 год, будут в нашей местности в пять или даже гораздо более того раз тяжелее текущего года, ибо в прошлом году был очень порядочный, а кое где и хороший урожай яровых полей и овощей, а в настоящем при огромной засухе из совсем нет...» $[8$, лл .23-24]. Вывод благочинного оказался неутешительным: крестьяне в будущем году опять будут бедствовать и пропитываться за счет средств земства и красного креста, что отразиться и на материальном положении сельских причтов. Клирик предлагает задуматься церковному начальству о судьбе приходского духовенства после закрытия Тульского епархиального комитета. Такие прогнозы и предложения встречаются в документах фондов церковного ведомства Тульской епархии в 1892 г. Работа комитетов по оказанию помощи голодающим, созданных в духовном ведомстве была хорошо заметной для современников - рядовых священно- и церковнослужителей, мирян. Прежде всего, на эти чрезвычайные органы возлагались надежды в аграрном социуме в голодные месяцы 1891-1892 гг.

Однако деятельность Русской Православной Церкви в один из наиболее трудных периодов, когда неурожай и голод охватил земледельческий Центр империи (1891-1892 гг.) теряется как в источниках, так и в историографии [2]. Крайне скупо характеризуется масштабная работа епархиальных комитетов по помощи голодающим в подробнейших «Всеподданнейших отчетах оберпрокурора Св. Синода» К. П. Победоносцева, нет в них и анализа деятельности ведущей конфессии в этот период, не отмечаются этом источнике и заслуги сельских клириков [1].

Подводя итоги, отметим, что организация благотворительной деятельности Русской Православной Церкви в период продовольственного кризиса 1891-1892 гг. была направлена на централизацию благотворительных усилий путем выстраивания «вертикали» комитетов по оказанию помощи голодающим -на уровне губернии (епархии), уезда и прихода. Деятельность Тульского епархиального комитета и его отделений является иллюстрацией успешного функционирования таких органов в губерниях земледельческого Центра Российской империи в сравнительно короткий период -сентябрь 1891-июнь 1892 гг. Однако напрашиваются и другие выводы.

Большая и сложная работа по выживанию аграрного социума в условиях массового голода была проделана усилиями священно-и церковнослужителей разного уровня- от епархиального архиерея до сельского дьячка или псаломщика. Но основная нагрузка пришлась на приходское духовенство, продемонстрировавшее в этот период высокий уровень социального служения. Для православного духовенства земледельческого Центра Российской империи, официально лишенного финансирования из государственного бюджета и вынужденного существовать за счет доброхотных пожертвований прихожан, терпящего экономическое бедствие, важным представлялось спасение практически единственного источника своего существования: крестьянина в отдельности и общины в целом. Сельский клир сам крайне нуждающийся, создавал комитеты вспомоществования при приходах, составлял подробные списки нуждающихся селян, распределял и контролировал поступившую помощь, просил за бедствующих псаломщиков, а также вдов и сирот духовного звания. И главное-вступал в диалог с местными помещиками, земскими начальниками, купцами, т. е. с основными фигурами на селе, имевшими материальные средства и влияние, включая их по возможности в состав приходских комитетов. Можно заключить, что Русская Православная Церковь, выстроив систему комитетов по оказанию помощи голодающим в пострадавших от неурожая губерниях, проявила свои мобилизационные возможности в сфере социального служения: не обладая материальными ресурсами, она обеспечила взаимодействие государственных, общественных, частных и церковных институтов. 


\section{Исторический журнал: научные исследования № 1 (31) • 2016}

DOI: $10.7256 / 2222-1972.2016 .1 .17309$

\section{Библиография:}

1. Всеподданнейший отчет Обер-прокурора Святейшего Синода по ведомству православного исповедания за 1890 и 1891 г. СПб., 1893.776 с.

2. Безгин В.Б. Правовые обычаи в обыденном сознании и повседневной жизни российского крестьянства второй половины XIX - начала XX века // Право и политика.-2013.-№10.-С. 1373-1380. DOI: 10.7256/1811-9018.2013.10.9640. URL: http://www.nbpublish.com/go_to_article.php?id=26017.

3. Вронский О. Г. Государственная власть России и крестьянская община рубеж XIX-XX вв.-1917 г. (по материалам губерний земледельческого центра страны): дисс...докт. истор. наук. М. 2001. 552 с.

4. Государственный архив Тульской области (ГАТО). Ф. 1373. Оп. 1. Д. 2. Журналы заседания губернского и сельских комитетов помощи голодающим, заявления голодающих и их списки, отчеты о работе комитетов и переписка с учреждениями и лицами о сборе денег в фонд голодающих (1891 г.)

5. ГАТО. Ф. 1373. Оп. 1. Д. 5. Протоколы мирских сходов и сведения приходских священников о количестве жителей, нуждающихся в продовольствии (1891 г.)

6. ГАТО. Ф. 1373 Оп. 1. Д. 12. Дело по рапортам священнослужителей о пожертвованиях в помощь голодающим (1891 г.)

7. ГАТО. Ф. 1373. Оп. 1. Д. 15. Рапорты и сведения приходских священников Ефремовского уезда об оказании помощи голодающим (1891-1892)

8. ГАТО. Ф. 1373. Оп. 1. Д. 21. Сведения благочинных и др. церковнослужителей о количестве жителей, нуждающихся в продовольствии (1891-1892 гг.)

9. ГАТО. Ф. 1373. Оп. 1. Д. 29. Отчет о деятельности Тульского епархиального комитета помощи голодающим (март 1892 г.).

10. ГАТО. Ф. 1373. Оп. 1. Д. 30. Отчет о деятельности Тульского епархиального комитета помощи голодающим с 1 марта по 1 мая (1892 г.).

11. ГАТО. Ф.3. Оп. 14. Д. 1711. Отчет о расходе денег на содержание епархиальной приходской столовой в селе Нижнее Скворчее Новосильского уезда Тульской губернии (1892 г.).

12. ГАТО. Ф З. Оп. 14. Д. 1681. Протокол заседания приходского комитета села Новозаголичное Ефремовского уезда о раздаче голодающим муки (26.05.1892).

13. ГАТО. Ф. 3 Оп.7 Д. 2812. Отчет комитета для помощи голодающим при Казанской церкви села Казанское-Греково Ефремовского уезда о приходе и расходе денежных сумм; ведомость семейств, получивших помощь от этого комитета (12.1891-03.1892)

14. ГАТО. Ф.З. Оп. 7. Д. 2967. Рапорт священника Георгиевской церкви села Закопы Ефремовского уезда Михаила Рождественского в Тульскую духовную консисторию о расходовании продуктов, полученных из Тульского епархиального комитета для помощи голодающим (29.07. 1892).

15. Калужские епархиальные ведомости. 1891. №17. Оффиц. часть.

16. Обзор Тульской губернии за 1891 год. Тула, 1892.127 с.

17. Прибавления к Тульским епархиальным ведомостям. 1891. 15 декабря. № 24.

18. Туманова А.С. Мобилизация гражданского общества России против неприятельских подданных в годы Первой мировой войны: организационный и правовой аспекты // Политика и Общество. - 2014. - № 7. - С. 733-739. DOI: 10.7256/18128696.2014.7.12553

19. Тульские епархиальные ведомости. 1891.1 сентября. № 17.

20. Тульские епархиальные ведомости. 1891.15 сентября. № 18.

21. Тульские епархиальные ведомости. 1891.1 декабря. № 23

22. Тульские епархиальные ведомости. 1891. 15-31 декабря. № 24

23. Тульские епархиальные ведомости. 1892.1 января. № 1.

24. Тульские епархиальные ведомости. 1892.1 апреля. № 7.

25. Тульские епархиальные ведомости. 1892. 1 мая. № 9.

26. Тульские епархиальные ведомости. 1892. 15 мая. № 10

27. Тульские епархиальные ведомости. 1892.15 июня. № 12.

28. Приходы и церкви Тульской епархии. Тула : Тип. Н. И. Соколова, 1895. 828 с.

29. Robbins R. G. Famine in Russia, 1891-1892. Columbia University Press.1975. 270 p.

\section{References (transliterated):}

1. Vsepoddanneishii otchet Ober-prokurora Svyateishego Sinoda po vedomstvu pravoslavnogo ispovedaniya za 1890 i $1891 \mathrm{~g}$. SPb., $1893.776 \mathrm{~s}$.

2. Bezgin V.B. Pravovye obychai $\mathrm{v}$ obydennom soznanii i povsednevnoi zhizni rossiiskogo krest'yanstva vtoroi poloviny XIX nachala XX veka // Pravo i politika.-2013.-№10.-C. 1373-1380. DOI: 10.7256/1811-9018.2013.10.9640. URL: http://www. nbpublish.com/go_to_article.php?id=26017.

3. Vronskii O. G. Gosudarstvennaya vlast' Rossii i krest'yanskaya obshchina rubezh XIX-XX vv.-1917 g. (po materialam gubernii zemledel'cheskogo tsentra strany): diss...dokt. istor. nauk. M. 2001. $552 \mathrm{s.}$

4. Gosudarstvennyi arkhiv Tul'skoi oblasti (GATO). F. 1373. Op. 1. D. 2. Zhurnaly zasedaniya gubernskogo i sel'skikh komitetov pomoshchi golodayushchim, zayavleniya golodayushchikh i ikh spiski, otchety o rabote komitetov i perepiska s uchrezhdeniyami $\mathrm{i}$ litsami o sbore deneg $\mathrm{v}$ fond golodayushchikh $(1891 \mathrm{~g}$.)

5. GATO. F. 1373. Op. 1. D. 5. Protokoly mirskikh skhodov i svedeniya prikhodskikh svyashchennikov o kolichestve zhitelei, nuzhdayushchikhsya v prodovol'stvii (1891 g.) 


\section{Верования, религии, Церкви}

DOI: $10.7256 / 2222-1972.2016 .1 .17309$

6. GATO. F. 1373 Op. 1. D. 12. Delo po raportam svyashchennosluzhitelei o pozhertvovaniyakh v pomoshch' golodayushchim (1891 g.)

7. GAT0. F. 1373. Op. 1. D. 15. Raporty i svedeniya prikhodskikh svyashchennikov Efremovskogo uezda ob okazanii pomoshchi golodayushchim (1891-1892)

8. GAT0. F. 1373. Op. 1. D. 21. Svedeniya blagochinnykh i dr. tserkovnosluzhitelei o kolichestve zhitelei, nuzhdayushchikhsya v prodovol'stvii (1891-1892 gg.)

9. GATO. F. 1373. Op. 1. D. 29. Otchet o deyatel'nosti Tul'skogo eparkhial'nogo komiteta pomoshchi golodayushchim (mart $1892 \mathrm{~g}$.).

10. GATO. F. 1373. Op. 1. D. 30. Otchet o deyatel'nosti Tul'skogo eparkhial'nogo komiteta pomoshchi golodayushchim s 1 marta po 1 maya (1892 g.).

11. GATO. F.3. Op. 14. D. 1711. Otchet o raskhode deneg na soderzhanie eparkhial'noi prikhodskoi stolovoi v sele Nizhnee Skvorchee Novosil'skogo uezda Tul'skoi gubernii (1892 g.).

12. GATO. F 3. Op. 14. D. 1681. Protokol zasedaniya prikhodskogo komiteta sela Novozagolichnoe Efremovskogo uezda o razdache golodayushchim muki (26.05.1892).

13. GATO. F. 3 Op.7 D. 2812. Otchet komiteta dlya pomoshchi golodayushchim pri Kazanskoi tserkvi sela Kazanskoe-Grekovo Efremovskogo uezda o prikhode i raskhode denezhnykh summ; vedomost' semeistv, poluchivshikh pomoshch' ot etogo komiteta (12.1891-03.1892)

14. GATO. F.3. Op. 7. D. 2967. Raport svyashchennika Georgievskoi tserkvi sela Zakopy Efremovskogo uezda Mikhaila Rozhdestvenskogo v Tul'skuyu dukhovnuyu konsistoriyu o raskhodovanii produktov, poluchennykh iz Tul'skogo eparkhial'nogo komiteta dlya pomoshchi golodayushchim (29.07.1892).

15. Kaluzhskie eparkhial'nye vedomosti. 1891. №17. Offits. chast'.

16. Obzor Tul'skoi gubernii za 1891 god. Tula, $1892.127 \mathrm{~s}$.

17. Pribavleniya k Tul'skim eparkhial'nym vedomostyam. 1891. 15 dekabrya. № 24.

18. Tumanova A.S. Mobilizatsiya grazhdanskogo obshchestva Rossii protiv nepriyatel'skikh poddannykh v gody Pervoi mirovoi voiny: organizatsionnyi i pravovoi aspekty // Politika i Obshchestvo. - 2014. - № 7. - S. 733-739. DOI: 10.7256/18128696.2014.7.12553

19. Tul'skie eparkhial'nye vedomosti. 1891.1 sentyabrya. № 17.

20. Tul'skie eparkhial'nye vedomosti. 1891.15 sentyabrya. № 18.

21. Tul'skie eparkhial'nye vedomosti. 1891. 1 dekabrya. № 23

22. Tul'skie eparkhial'nye vedomosti. 1891. 15-31 dekabrya. № 24

23. Tul'skie eparkhial'nye vedomosti. 1892. 1 yanvarya. № 1 .

24. Tul'skie eparkhial'nye vedomosti. 1892.1 aprelya. № 7 .

25. Tul'skie eparkhial'nye vedomosti. 1892.1 maya. № 9.

26. Tul'skie eparkhial'nye vedomosti. 1892.15 maya. № 10

27. Tul'skie eparkhial'nye vedomosti. 1892. 15 iyunya. № 12 .

28. Prikhody i tserkvi Tul'skoi eparkhii. Tula : Tip. N. I. Sokolova, $1895.828 \mathrm{~s}$.

29. Robbins R. G. Famine in Russia, 1891-1892. Columbia University Press.1975. 270 p. 